\title{
E-Learning berbasis Edmodo untuk Optimalisasi Pembelajaran Pada Masa New Normal
}

\author{
Gellysa Urva ${ }^{1}$, Merina Pratiwi ${ }^{2}$, Amiroel Oemara Syarief ${ }^{3}$ \\ 1,2Program Studi Teknik Informatika, ${ }^{3}$ Program Studi Teknik Industri \\ Sekolah Tinggi Teknologi (STT) Dumai \\ *e-mail: gellysa.urva@gmail.com¹, merinapratiwi1920@gmail.com, oemara.syarief@gmail.com
}

\begin{abstract}
The impact of Covid-19 is that every educator is required to use E-Learning as a mediation for teaching and learning activities in the world of education. Through Edmodo-based E-Learning, educators can share content, text, videos and assignments to students online. In fact, the weakness of educators in the use of e-learning media as a support for the learning process is the theme raised in this training. The solution offered from this training is Edmodo-based $E$ Learning media. The objects of this training activity are educators and parents of students and related parties. This training provides many benefits to the object of training, this can be seen from the commitment of the training participants about the plan to implement Edmodo-based ELearning media in the next learning class. The results of the evaluation of the implementation of this training show that this training is useful to support the teaching and learning process carried out at schools and on campus. The training method is able to improve the skills of educators in using Edmodo-based E-Learning media, both as teachers, lecturers, students, students and parents involved.
\end{abstract}

Keywords: Covid-19, E-Learning, Edmodo, Educator

\begin{abstract}
Abstrak
Dampak dari Covid-19 setiap Pendidik diharuskan menggunakan E-Learning sebagai mediasi kegiatan belajar mengajar di dunia pendidikan. Melalui E-Learning berbasis Edmodo Pendidik dapat membagikan konten, teks, video dan tugas kepada peserta didik secara online. Permalahan yang terjadi lemahnya pendidik dalam penggunaan media e-learning sebagai penunjang proses pembelajaran menjadi tema yang diangkat dalam pelatihan ini. Solusi yang ditawarkan dari pelatihan ini adalah media E-Learning berbasis Edmodo. Objek kegiatan pelatihan ini adalah Pendidik Serta Orang Tua Peserta didik dan yang terkait. Pelatihan ini memberikan banyak manfaat kepada objek pelatihan, hal ini terlihat dari komitmen peserta pelatihan tentang rencana penerapan media E-Learning berbasis Edmodo dalam kelas pembelajaran selanjutnya. Hasil evaluasi pelaksanaan pelatihan ini menunjukkan bahwa pelatihan ini bermanfaat untuk menunjang proses belajar mengajar yang dilakukan di sekolah maupun di kampus. Metode pelatihan mampu meningkatkan keterampilan pendidik dalam menggunakan media E-Learning berbasis Edmodo, baik sebagai guru, dosen,siswa, mahasiswa maupun orang tua yang terlibat.
\end{abstract}

Kata kunci: Covid-19, E-Learning, Edmodo, Pendidik

\section{PENDAHULUAN}

Covid-19 merupakan virus yang merupakan virus RNA strain tunggal positif ini menginfeksi saluran pernafasan. Penegakan diagnosis dimulai dari gejala umum berupa demam, batuk, dan sulit bernafas hingga adanya kontak erat dengan Negaranegara yang sudah terinfeksi. Pengambilan swab tenggorokan dan saluran napas menjadidasar penegakan Diagnosis Coronavirus Disease. Covid-19 bermula muncul dari Wuhan Cina sejak Akhir Januari 2020. Organisasai kesehatan dunia (WHO) telah menetapkan penomena kejadian itu sebagai pandemic (Mahase, 2020). Pada saat ini Indonesia dihadapkan pada tantangan besar untuk menangani dan mencegah penyebaran virus Covid-19 yang semakin menyebar, yang berdampak pada semua aspek kehidupan. Salah satu bidang yang paling signifikan adalah bidang pendidikan. 
Lembaga pendidikan sekolah/ perguruan tinggi sebagai ujung tombak pelayanan pendidikan pada level paling bawah. Para pimpinan Perguruan tingi/kepala sekolah dipaksa oleh keadaan untuk sesegera membuat suatu keputusan atau kebijakan teknis untuk merespon kebijakan surat edaran perintah dari mendikbud yang mengharuskan layanan pendidikakan atau "pembelajaran dari rumah" mulai dari Taman kanak-kanak hingga Perguruan tinggi (Kemendikbud, 2020). Sistem pendidikan di perguruan tinggi berubah secara signifikan pada awal tahun 2020, khususnya pada bulan Maret 2020 . Pada masa pandemi Covid-19 kegiatan pembelajaran tidak bisa dilaksanakan secara tatap muka di kelas. Pembatasan interaksi sosial di berbagai tempat mengharuskan pembelajaran dilakukan dengan daring. Pembelajaran dalam jaringan (daring) menjadi solusi agar pembelajaran tetap dapat dilakukan dimana saja dan kapan saja. Upaya pencegahan penyebaran Covid-19 yang dilakukan Kementerian pendidikan dan Kebudayaan terhadap lembaga pendidikan, yaitu dengan kebijakan belajar dari rumah, melalui pembelajaran daring dan luring dengan aturan tertentu yang dikenal dengan masa new normal (Aditya, 2016). Pembelajaran daring merupakan pembelajaran yang dilakukan menggunakan internet sebagai tempat menyampaikan informasi dengan bentuk pembelajaran seperti yang dapat dilakukan kapanpun dan dimanapun tanpa terikat waktu dan tanpa harus bertatap muka dengan berbagai aplikasi dan fitur yang semakin memudahkan pengguna (Syarifudin, 2020).

Penggunaan dan pemanfaatan berbagai platform online menjadi kemampuan yang harus dikuasai oleh Para Pendidik untuk implementasi pembelajaran daring di masa new normal. Berbagai media E-Learning telah dapat digunakan baik oleh guru, dosen, mahasiswa maupun siswa seperti google classroom, moodle, Edmodo, zoom, dan sebagainya (Rusdiana, 2020). Masing-masing media E-Learning tersebut memiliki keunggulan tersendiri sehingga menjadi pertimbangan bagi Pendidik untuk dapat menggunakannya (Sasanti,2020). Salah satu platform online yang ditawarkan berdasarkan perkembangan ICT saat ini adalah media E-Learning berbasis Edmodo. Edmodo dikembangkan berdasarkan prinsip-prinsip pengelolaan kelas berbasis kelompok dan juga sosial media (Aprilia, 2020). Edmodo sangat komprehensif sebagai sebuah course management system seperti Moodle, bedanya adalah aksesnya lebih cepat dan lebih mudah menggunakannya dengan menggunakan beberapa fitur yang fungsinya sama seperti course management system (Dharmawati, 2017). Penggunaan edmodo bukan hanya Pendidik dan Peserta Didik saja yang dapat berinteraksi, tetapi para orang tua dari peserta didik juga dapat memiliki akun untuk ikut berkomunikasi dengan Pendidik. Edmodo menyediakan cara yang aman dan mudah bagi kelas untuk terhubung dan berkolaborasi antara Peserta Didik dan Pendidik untuk berbagi konten pendidikan, mengelola proyek dan tugas dan menangani pemberitahuan setiap aktivitas. Edmodo dapat membantu Pendidik membangun sebuah kelas virtual sesuai dengan kondisi pembelajaran di dalam kelas, berdasarkan pembagian kelas nyata di sekolah maupun di kampus, dimana dalam kelas tersebut terdapat penugasan, quiz dan pemberian nilai pada setiap akhir pembelajaran. Pelatihan E-Learning berbasis Edmodo ini diharapkan dapat mengoptimalkan pengetahuan terhadap para Pendidik yang belum menggunakan media E-Learning khusus pembelajaran ataupun yang sudah menggunakan media E-Learning pembelajaran tetapi bukan Edmodo. Pengetahuan yang para Pendidik dapatkan tentang media E-Learning berbasis Edmodo ini diharapkan dapat membantu proses pembelajaran di kelas, serta membantu Pendidik dalam menciptakan proses pembelajaran daring maupun luring yang tidak monoton (Zutiasari,2021). 


\section{METODE}

Metode yang digunakan Penulis dalam pelaksanaan program pelatihan ini meliputi persiapan pelaksanaan program, proses pelatihan, pendampingan hingga melakukan evaluasi setelah kegiatan pelatihan. Adapun tujuan penerapan metode ini yaitu untuk memberikan pemahaman secara umum terkait media E-Learning berbasis Edmodo yang meliputi pengenalan aplikasi, tujuan pembuatan, serta manfaat aplikasi. Tahap selanjutnya yaitu pemberian pelatihan mengenai cara pengoperasian Aplikasi Edmodo. Hal ini dimaksudkan agar seluruh Pendidik dapat memanfaatkan aplikasi, mengoperasikan aplikasi sehingga memberikan variasi media dalam kegiatan belajar mengajar secara jarak jauh. Sosialisasi dan pelatihan ini diikuti oleh Para Pendidik baik Guru atau Dosen serta Orang Tua dan pihak lainnya yang bergabung. Pada tahap persiapan, penulis terlebih dahulu melakukan observasi terkait penentuan tema yang akan diangkat pada pelatihan yang disesuaikan dengan kebutuhan dimasanya. Selanjutnya dilakukan serangkaian persiapan lain seperti mempersiapkan materi pelatihan yang mudah untuk dipahami dan mempersiapkan media penyampaian kepada Pendidik dengan menggunakan model presentasi yang dilakukan oleh Pemateri. Setelah persiapan pelaksanaan program pelatihan E-Learning berbasis Edmodo ini selesai dilakukan, dilanjutkan dengan tahap proses implementasi program pengabdian. Pada akhir kegiatan implementasi, setiap peserta wajib mengisi quisioner yang diberikan Penulis sebgai respon sasaran program terhadap kegiatan implementasi yang dilakukan. Pada Gambar 1 berikut, alur metode pelaksanaan Pelatihan ELearning berbasis Edmodo yang diterapkan.

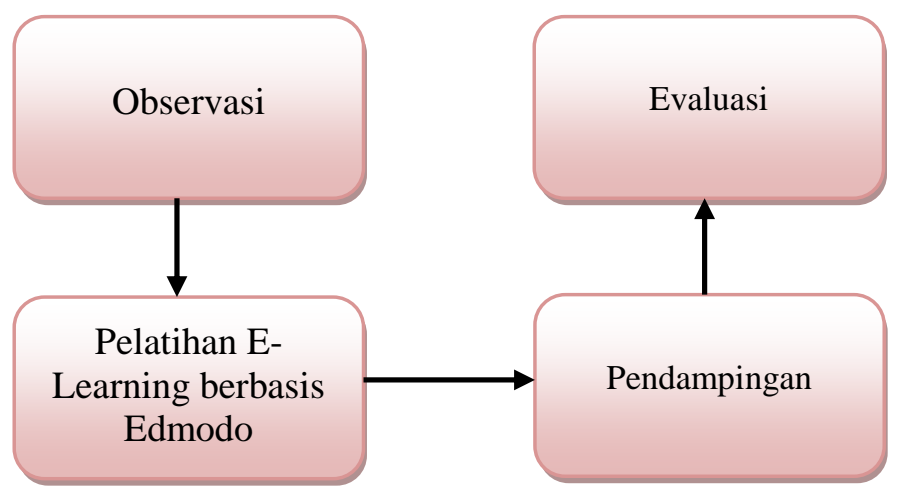

Gambar 1. Alur Metode Pelaksanaan

Pelatihan ini dilaksanakan secara sistematis secara online menggunakan platform Zoom Meeting pada hari Jum'at tanggal 20 Mei 2020. Pelaksanaan pelatihan ini dilakukan dengan dua pendekatan yaitu ceramah dan demonstrasi. Pendekatan ceramah dilakukan pada saat penyampaian materi inti secara langsung oleh narasumber. Sedangkan demonstrasi dilakukan secara syncronious untuk awal materi pengenalan Edmodo oleh narasumber dan dilanjutkan menggunakan E-Learning berbasis Edmodo untuk pendampingan eksplorasi tugas-tugas yang mendalam oleh peserta. Materi yang dipaparkan oleh penulis dapat dilihat pada Tabel 1.

Tabel 1. Materi Pelatihan E-Learning berbasis Edmodo

NO Uraian Materi

1 Pengenalan Pembelajaran E-Learning serta Pemaparan pemanfaatan teknologi dalam Pendidikan 
$2 \quad$ Merancang rencana pembelajaran model daring

3 Pengenalan Edmodo termasuk Struktur / Framework Edmodo

4 Create Account Student pada Edmodo

5 Create Account Teacher pada Edmodo

6 Create Account Parent pada Edmodo

$7 \quad$ Membuat Group di Edmodo

$8 \quad$ Pembuatan kelas menggunakan Edmodo

9 Cara Membuat tugas dan kuis pada Edmodo

10 Pemanfaatan manajemen file menggunakan library dan cloud

\section{HASIL DAN PEMBAHASAN}

Hasil dari pelatihan yang dilakukan menunjukkan bahwa pembelajaran daring menggunakan E-Learning berbasis Edmodo mampu mengoptimalkan peningkatan aktivitas belajar peserta didik dari sebelumnya. Merekap dari hasil E-Kuisioner yang diberikan, persentase aktivitas belajar daring peserta didik hanya sebesar $35 \%$. Sebagian besar peserta didik tidak aktif atau enggan mengikuti pembelajaran daring karena dirasa membosankan. Setelah menggunakan aplikasi Edmodo, aktivitas belajar peserta didik meningkat $40 \%$ menjadi $75 \%$. Peserta didik sangat antusias mengikuti pembelajaran karena mereka senang dengan fitur-fitur yang ada di Edmodo. Akhir pelatihan ditutup dengan pengisian e-kuesioner yang dapat peserta isi di laptop ataupun handphone masing- masing secara online. E-kuesioner telah dipersiapkan sebelumnya oleh pemateri dengan menggunakan form. E- kuesioner ini dilakukan untuk mengetahui respon para peserta mengenai pelatihan ini. Kuisioner ini diisi oleh 20 orang yang merupakan peserta pelatihan. Beberapa pernyataan pada kuesioner diukur dengan skala Likert 1-4. Pernyataan kuesioner digunakan untuk menilai 4 (empat) aspek yaitu pelayanan, pemateri, manfaat, dan protokol kesehatan. Pada kuesioner juga disediakan tempat untuk peserta pelatihan dapat menyampaikan saran dan kritiknya. Akhir pelatihan ditutup dengan pengisian e-kuesioner yang dapat peserta isi di laptop ataupun handphone masing- masing secara online. E-kuesioner telah dipersiapkan sebelumnya oleh pemateri dengan menggunakan form. E- kuesioner ini dilakukan untuk mengetahui respon para peserta mengenai pelatihan ini. Kuisioner ini diisi oleh 20 orang yang merupakan peserta pelatihan. Beberapa pernyataan pada kuesioner diukur dengan skala Likert 1-4. Pernyataan kuesioner digunakan untuk menilai 4 (empat) aspek yaitu pelayanan, pemateri, manfaat, dan protokol kesehatan. Pada kuesioner juga disediakan tempat untuk peserta pelatihan dapat menyampaikan saran dan kritiknya. Beberapa hasil kuesioner dengan pertanyaan 'Secara keseluruhan, seberapa baik pelatihan ini dalam hal?' yang disajikan pada tabel 2 berikut. 
Tabel 2. Hasil Kuisioner

\begin{tabular}{llccc}
\hline & & \multicolumn{3}{c}{ Respon Peserta } \\
NO & \multicolumn{1}{c}{ Pertanyaan } & Sangat Baik & Baik & $\begin{array}{c}\text { Cukup } \\
\text { Baik }\end{array}$ \\
\cline { 2 - 5 } $\mathbf{1}$ & Kualitas Pelayanan Pelatihan & 12 & 8 & 0 \\
\hline $\mathbf{2}$ & Kualitas Pemaparan Pemateri & 7 & 13 & 0 \\
\hline $\mathbf{3}$ & Manfaat untuk Peserta & 15 & 5 & 0 \\
$\mathbf{4}$ & $\begin{array}{l}\text { Pelaksanaan } \\
\text { Kesehatan }\end{array}$ & 18 & 2 & 0 \\
\hline
\end{tabular}

Setelah pemberian kesan dan pesan dari peserta, pelatihan Edmodo ini ditutup dengan foto bersama yang dilakukan secara daring antara panitia penyelenggara, pemateri, dan peserta dapat dilihat pada gambar 2 .

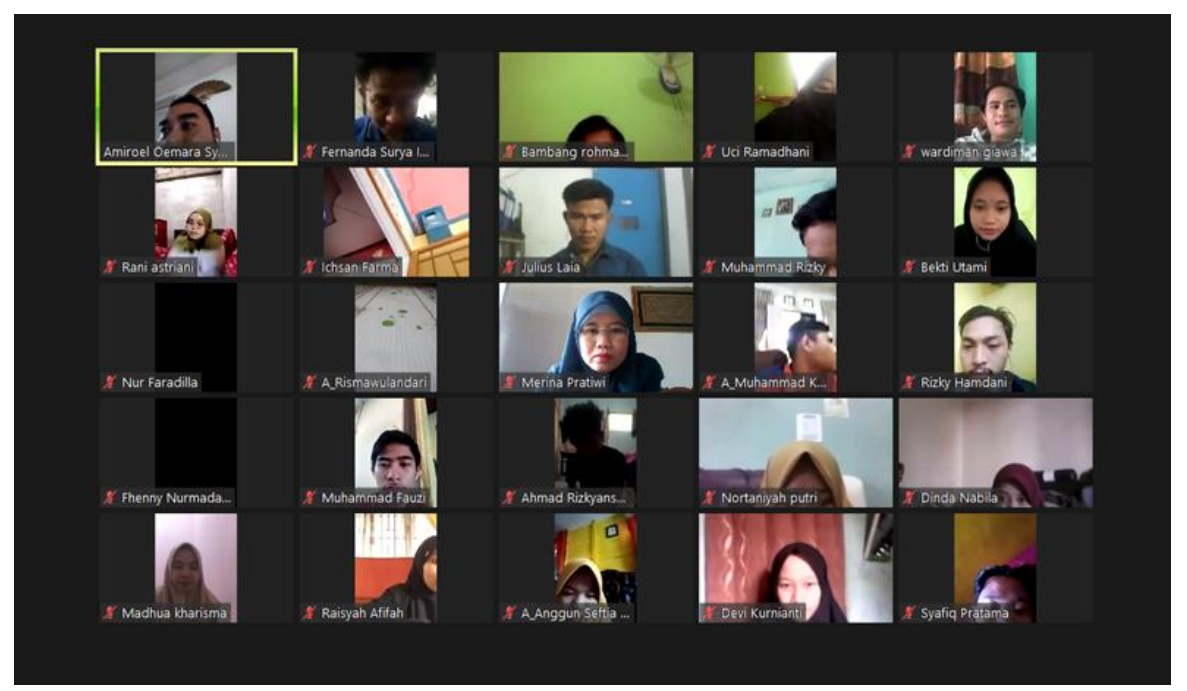

Gambar 2. Peserta Pelatihan

\section{KESIMPULAN}

Pelatihan media E-Learning berbasis Edmodo ini telah memberikan pengetahuan baru bagi Para Pendidik Khususnya serta Orang Tua dan pihak yang terkait, sehingga Peserta Pelatihan dapat menjadikan Edmodo ini sebagai option yang dapat mereka gunakan dalam proses pembelajaran daring yang mereka lakukan. Edmodo ini memiliki keunggulan sendiri dibandingkan media e-learning lainnya. Media E-Learning berbasis Edmodo ini merupakan salah satu media E-Learning yang dapat meningkatkan proses belajar mengajar yang lebih menarik dikarenakan memiliki fitur/tampilan seperti halnya media social yang sering digunakan peserta didik di sehari-hari. Tampilan menarik merupakan salah satu keunggulan dari Edmodo. Selain itu, orang tua dapat mengawasi proses belajar anaknya secara langsung. Tidak perlu lagi bertanya perkembangan anaknya ke Guru atau Dosennya, orang tua dapat mengawasinya secara langsung dengan menggunakan Edmodo bagi orang tua. 
Pelatihan E-Learning berbasis Edmodo ini telah terlaksana secara baik terbukti karena seluruh peserta mengikuti setiap sesi kegiatan dengan sangat serius dan antusias. Pelaksanaan kegiatan pelatihan ini telah berlangsung dengan baik, tertib, dan sesuai dengan jadwal yang telah ditentukan. Pelaksanaan kegiatan ini dapat dinyatakan berhasil mencapai tujuan yang telah ditentukan dengan tercapainya tolak ukur keberhasilan yang ditentukan oleh tim penulis. Para peserta pelatihan mendapat pengetahuan baru serta meningkatkan wawasan tentang penggunaan Edmodo sebagai media E-Learning yang menarik dan menyenangkan serta sangat optimal digunakan pada masa new normal saat ini.

\section{UCAPAN TERIMA KASIH}

Penulis berterimakasih kepada Tim Penulis yaitu dosen-dosen Sekolah Tinggi Teknologi Dumai yang telah merencanakan kegiatan ini secara cukup matang dan melaksanakan kegiatan ini dengan baik dan lancar. Tidak lupa penulis pun berterima kasih kepada Pihak yang turut membantu.

\section{DAFTAR PUSTAKA}

Aditya, D. Y. (2016). Pengaruh Penerapan Metode Pembelajaran Resitasi terhadap Hasil Belajar Matematika Siswa. SAP (Susunan Artikel Pendidikan), 1(2), 165174.

Aji, R. H. S. (2020). Dampak Covid-19 pada Pendidikan di Indonesia: Sekolah, Keterampilan, dan Proses Pembelajaran. Salam: Jurnal Sosial Dan Budaya Syar-I, 7(5): 395-402.

Aprilia Riska \& Nurdian Yudha, (2020). Pendampingan Dan Peningkatan Kecakapan Guru, Wali Murid, Dan Peserta Didik Dalam Pembelajaran Daring. Jurnal Pengabdian Masyarakat, Monsu'ani Tano, 3(2), 86-95.

Dharmawati. (2017). Penggunaan Media E- Learning Berbasis Edmodo dalam Pembelajaran English for Business QUERY : Jurnal Sistem Informasi. Jurnal Sistem Informasi, 1(1), 43-49

G. Ngurah et al., (2019). Pelatihan Media Daring Penunjang Pembelajaran Edmodo di SDN Tulangampiang. Jurnal Ilmiah Populer , 3(2), 37-43

G. S. D. K. Cawas, (2020). Implementasi E-Learning Menggunakan Edmodo bagi Guru-guru SD. Abdimasku, 3(1) 56-64

Mahase, E. (2020). Coronavirus Covid-19 has Killed more People than SARS and MERS combined, Despite Lower Case Fatality Rate. BMJ (Clinical Research Ed.),368(February), m641. https://doi.org/10.1136/bmj.m641

Merona, S. P. (2017). Kombinasi Tutorial dengan Metode Tanya Jawab untuk Meningkatkan Pemahaman Matematika Di Perguruan Tinggi, 6(2), 153-162.

R. D. Sasanti, (2020). Pengajuan Masalah Berbantuan Edmodo Sebagai Upaya Meningkatkan Keaktifan Siswa Di Era Pandemi Covid-19. EULER: Jurnal Ilmiah Matematika, Sains dan Teknologi, 8(2), 60-69. DOI: https://doi.org/10.34312/euler.v8i2.10417

R. R. Sani, D. W. Utomo, D. Kurniawan, F. I. Komputer, and U. D. Nuswantoro, (2020). Penerapan Edmodo bagi Guru dan Murid SMK Karya Bhakti Brebes sebagai Media Belajar Tambahan. Abdimasku, 3(2), 34-39

Rusdiana, A., Sulhan, M., Arifin, I. Z., \& Kamludin, U. A. (2020). Penerapan Model POE2WE Berbasis Blended Learning Google Classroom Pada Pembelajaran Masa WFH Pandemic Covid-19. Karya Tulis Ilmiah UIN Bandung 
ABDINE: Jurnal Pengabdian Kepada Masyarakat Vol. 01, No. 01, Juni 2021, Hal. 41 - 47

Syarifudin, A. S. (2020). Impelementasi Pembelajaran Daring Untuk Meningkatkan Mutu Pendidikan Sebagai Dampak Diterapkannya Social Distancing. Jurnal Pendidikan Bahasa Dan Sastra Indonesia Metalingua, 5(1), 31-34

Zutiasari, W. P. Rahayu, \& J. A. Martha, (2021). Pemanfaatan E- Learning Network Edmodo Dalam Pembelajaran. Jurnal Dedication, 5(1), 87-94

Kemendikbud (2020). Cegah Sebaran Covid-19 di Satuan Pendidikan, Kemendikbud Gandeng Swasta Siapkan Solusi Belajar Daring (Siaran Pers BKH Kemendikbud Nomor: 054/SIPRES/A6/ III/2020. 15 Maret 2020). 